\title{
Regulation of Galanin Gene Expression in Gonadotropin- Releasing Hormone Neurons during the Estrous Cycle of the Rat*
}

\author{
DANIEL L. MARKS, M. SUSAN SMITH, MARIA VRONTAKIS, DONALD K. CLIFTON, \\ AND ROBERT A. STEINER \\ Departments of Physiology and Biophysics (D.L.M., R.A.S.) and Obstetrics and Gynecology (D.K.C., R.A.S.), \\ University of Washington, Seattle, Washington 98195; the Department of Physiology, University of \\ Pittsburgh (M.S.S.), Pittsburgh, Pennsylvania 15261; and the Department of Physiology, University of \\ Manitoba (M.V.), Winnipeg, Manitoba, Canada
}

\begin{abstract}
Galanin is colocalized with $\mathrm{GnRH}$ in neurons of the hypothalamus and basal forebrain of female rats, and this neuropeptide may play a role in the generation of the midcycle surge of gonadotropin secretion. We tested the hypothesis that galanin gene expression in $\mathrm{GnRH}$ cells increases during proestrus. To accomplish this, we killed groups of adult female rats at 1200 and $1800 \mathrm{~h}$ on the day of proestrus as well as at $1800 \mathrm{~h}$ on the day of estrus and used double labeling in situ hybridization and image analysis to estimate and compare the levels of galanin mRNA in cells coexpressing GnRH mRNA. GnRH mRNA was detected with an antisense cRNA probe labeled with the hapten digoxigenin, while the galanin cRNA probe was labeled with ${ }^{35} \mathrm{~S}$ and detected by autoradiography. There was no significant difference in the total number of GnRH cells identified in each animal in any of the different groups in any experiment. The relative number of silver grains over these cells, reflecting galanin mRNA content in GnRH neurons (identified by their purple color), was counted with a computerized image analysis system. In an initial experiment, we observed a 2 -fold $(P<$ 0.03 ) higher galanin mRNA signal level in the animals killed at $1800 \mathrm{~h}$ than in those killed at $1200 \mathrm{~h}$ on the day of proestrus. Animals killed at $1800 \mathrm{~h}$ on the day of estrus had galanin mRNA signal levels that were not statistically different from those in the proestrous $1800 \mathrm{~h}$ group, indicating that the increase in galanin mRNA at proestrus is
\end{abstract}

maintained for at least $24 \mathrm{~h}$. Galanin mRNA levels in $\mathrm{GnRH}$ neurons returned to basal levels equivalent to those in the proestrous $1200 \mathrm{~h}$ group by $1000 \mathrm{~h}$ on diestrous day 1 . In conjunction with the studies of galanin gene expression in $\mathrm{GnRH}$ neurons, we compared the relative cellular contents of GnRH mRNA among the same groups. Here, we used single labeling isotopic in situ hybridization for GnRH mRNA and computerized image analysis to count the resulting silver grains. We could detect no difference in GnRH mRNA signal levels (proestrus, $1200 \mathrm{~h} v$ s. proestrus, $1800 \mathrm{~h} v$ s. estrus, $1800 \mathrm{~h}$ ). In a final experiment, we investigated the possible role of estrogen in the induction of galanin mRNA expression at proestrus by comparing relative galanin mRNA contents in GnRH neurons among groups of ovariectomized, intact (diestrous day 1), and ovariectomized $17 \beta$-estradiol-replaced female rats. We observed a significant $(P<0.006)$ decrease in galanin mRNA levels in ovariectomized animals relative to diestrous day 1 animals, which was blocked by estradiol replacement. We conclude that galanin mRNA levels in GnRH neurons of the female rat are increased during proestrus and that the rise in plasma estrogen occurring early in proestrus may stimulate expression of galanin mRNA. These observations suggest that an increase in galanin gene expression subserves increases in the synthesis and secretion of galanin by GnRH neurons, which could enhance the ability of cosecreted $\mathrm{GnRH}$ to stimulate gonadotropin release at the time of the preovulatory surge. (Endocrinology 132: 1836-1844, 1993)
G AI.ANIN is a gut-brain peptide produced in hypothalamic neurons and the anterior pituitary $(1,2)$. Based on several lines of evidence, galanin is thought play a role in the regulation of the secretion and activity of hormones governing reproductive function $(3,4)$. Pharmacological administration of galanin into the brain evokes LH release (5), acting either through receptors in the median eminence (6) or via a direct effect on pituitary gonadotropes (4). Furthermore, galanin content in the hypothalamus of female rats increases near the time of the proestrous surge of gonadotropins (7), suggesting that galanin participates in the neuroendocrine control of ovulation. Galanin is also colocalized with $\mathrm{GnRH}$ in a subset of hypothalamic neurons. Studies in which either immunocytochemistry (7) or in situ hybridization (8)

Received October 23, 1992

Address all correspondence and requests for reprints to: Dr. Robert A. Steiner, University of Washington, RH-20, Seattle, Washington 98195.

* This work was supported by USPHS (NIH) Grants HD-12652 and HD-12629. was employed have demonstrated that the galanin gene is expressed in $50-65 \%$ of hypothalamic GnRH neurons in female rats, indicating that in addition to $\mathrm{GnRH}$ itself, galanin expression in GnRH neurons may be an important component in the regulation of gonadotropin release. Collectively, these observations imply a physiological function for galanin in the neuroendocrine regulation of gonadotropin secretion.

We wished to examine whether the expression of galanin mRNA changes across the estrous cycle and determine whether estrogen regulates the expression of galanin mRNA in GnRH neurons. To accomplish these objectives, we used double labeling in situ hybridization to identify $\mathrm{GnRH}$ mRNA-containing neurons and simultaneously to estimate cellular levels of galanin mRNA in these cells.

$\Lambda$ though galanin may play a role in the modulation of interactions between the hypothalamus and the anterior pituitary, GnRH is the primary regulator of pituitary gonadotropin synthesis and secretion (9-11). In female rats, the enhanced discharge of $\mathrm{LH}$ observed on the afternoon of proestrus (12-14) is associated with an increase in the expres- 
sion of the protooncogene product of the c-fos gene, cTos, in GnRH neurons, indicating that these cells are activated (1520). Although evidence that GnRH neurons are activated at proestrus is compelling, understanding of the cellular and molecular events occurring as a result of this activation is limited. Measurements of GnRH gene expression during the estrous cycle have yielded variable results (21-23), and although estrogen is known to be elevated at proestrus, it has been reported to impose inhibitory (24-26), stimulatory (2729 ), or no (21) effects on GnRH gene expression. To clarify this issue, we examined the regulation of cellular levels of $\mathrm{GnRH}$ gene expression at times during the estrous cycle. We used single labeling in situ hybridization to measure relative cellular GnRH mRNA content and determine whether these levels change when $\mathrm{GnRH}$ neurons are activated at proestrus (20).

\section{Materials and Methods}

\section{Animals}

Adult female Sprague-Dawley rats were purchased from Simonsen Laboratories (Gilroy, CA) and housed under constant 14-h light 10-h dark conditions, with lights on at $0600 \mathrm{~h}$. The animals had free access to rat chow and tap water. The estrous cycle of the animals was monitored by daily vaginal lavage. Only females having completed at least two consecutive 4-day cycles were included in the study. In Exp 4, ovariectomy was performed under ether anesthesia, with sham or estradiol implants inserted at the time of surgery.

\section{Experimental design}

Exp 1. We examined the influence of the stage of the estrous cycle on expression of the galanin mRNA in $\mathrm{GnRH}$ neurons using a double in situ hybridization protocol (10) to identify GnRH mRNA-positive cells for analysis of their relative galanin mRNA content. In addition, an estimate of the relative cellular galanin mRNA content in non-GnRH neurons was made as well as a count of the total number of $\mathrm{GnRH}$ neurons identified in the sections examined. Experimental groups included animals that were killed on the day of proestrus at $1200 \mathrm{~h}$ ( $\mathrm{n}=$ $3)$ and $1800 \mathrm{~h}(\mathrm{n}=4)$ and those killed on the day of estrus $(1800 \mathrm{~h}$; $\mathrm{n}$ $=3$ ).

Exp 2. To confirm and extend the findings of Exp 1, animals were killed on the day of proestrus $[1200 \mathrm{~h}(\mathrm{n}=3)$ and $1800 \mathrm{~h}(\mathrm{n}=4)]$, the day of estrus (1800 $h ; n=3$ ), and diestrous day 1 (diestrus $1 ; 1000 h ; n=4$ ). We then used double labeling in situ hybridization to estimate and compare among groups the relative cellular galanin mRNA levels in GnRH neurons.

Exp 3. We examined the influence of the stage of the estrous cycle on the expression of GnRH mRNA in individual neurons and the number of GnRH mRNA-positive ncurons throughout the basal forebrain and rostral hypothalamus of adult female rats. An alternate set of brain sections from the animals used in Exp 1 was used for this experiment. Using a radiolabeled cRNA probe and in situ hybridization, we compared the relative cellular GnRH mRNA contents in individual neurons and counted the total number of GnRH neurons in the tissue sections examined.

Exp 4. In this experiment, we sought direct evidence for estrogen regu lation of the galanin gene in GnRH neurons. We approached this by comparing cellular contents of galanin mRNA in GnRH neurons amerg groups of animals exposed to different levels of circulating estradiol. Two groups of ovariectomized (OVX) animals were implanted with 10$\mathrm{mm}$ Silastic capsules; one group received capsules filled with cholesterol (sham; $n=6$ ), while the other received $10-\mathrm{mm}$ capsules filled with crystalline $17 \beta$-estradiol and cholesterol in a $1: 1$ mixture. These two groups of animals were killed 21 days after surgery and prepared for double labeling in situ analysis. A third group of intact female animals was killed at $1100 \mathrm{~h}$ on diestrus $1(n=6)$ and included in the experimental analysis.

\section{Tissue preparation}

Animals were killed by asphyxiation with carbon dioxide and immediately decapitated. The brains were rapidly removed, frozen on dry ice, and stored at $-80 \mathrm{C}$. Coronal brain slices $(20 \mathrm{~mm})$ were cut with a cryostat, thaw-mounted onto poly-L-lysine $(50 \mathrm{mg} / \mathrm{ml})$-coated slides, and stored at $-80 \mathrm{C}$ in air-tight boxes. Using the rat atlas of Paxinos and Watson (30) as an anatomical guide, we collected coronal slices beginning rostrally at the genu of the corpus callosum and continuing caudally through the decussation of the anterior commissure. The sections were collected on three sets of slides, with each set representing a one in three series of sections over the entire rostral to caudal extent of sectioning.

\section{Probe preparation}

A detailed methodology for single and double label in situ hybridization has been previously reported, and the descriptions that follow briefly iterate this methodology and identify any significant changes specific to this group of experiments. A 462-basepair (bp) ${ }^{35} \mathrm{~S}$-labeled cRNA probe, complementary to rat GnRH mRNA, was used for single label hybridization histochemistry. The original plasmid containing the GnRH insert, previously described in detail $(8,31)$, was generously provided by Tony Mason (Genentech, South San Fransisco, C.A). After in vitro probe synthesis, with $14 \%$ of the total UTP replaced with $\left.{ }^{35} S\right]$ UTP, the probe was added to the hybridization buffer to obtain a final concentration of $0.25 \mu \mathrm{g} / \mathrm{ml}$. kilobase. The control experiments used to validate the integrity, binding kinetics, and specificity of the GnRH cRNA probe have been previously described $(32,33)$.

A digoxigenin-labeled cRNA probe for $\mathrm{GnRH}$ mRNA was made from the same plasmid used for synthesis of the ${ }^{35} \mathrm{~S}$-labeled probe. The probe was synthesized in vitro from linearized DNA with $400 \mathrm{~mm}$ digoxigenin11-U'TP (Boehringer Mannheim, Indianapolis, IN), $100 \mathrm{~mm}$ unlabeled UTP, 500 mM GTP, ATP, CTP, and SP6 polymerase. Residual DNA was digested with DNAase, and the CRNA probe was separated from unincorporated nucleotides on a Sephadex G-50 column. The purified probe was diluted 1:40 in hybridization buffer for double label hybridization histochemistry.

The plasmid vector Bluescript containing a cDNA complimentary to rat galanin mRNA (2) was used to generate the galanin cRNA probe. This plasmid was used for in vitro transcription of a $680-\mathrm{bp}{ }^{35} \mathrm{~S}$-labeled cRNA probe for galanin mRNA and control unlabeled cRNA. The galanin probe transcription reactions had $25 \%$ of their total UTP as $\left[{ }^{35} \mathrm{~S}\right]$ UTP. The final double label hybridization solution contained a galanin cRNA probe concentration of $0.30 \mu \mathrm{g} / \mathrm{ml} \cdot$ kilobase.

Before the double label hybridization procedure, both the ${ }^{35} \mathrm{~S}$-labeled galanin cRNA probe and the digoxigenin-labeled GnRH cRNA probe were heat denatured and added to hybridization buffer. Since the exact yield of the transcription reaction with digoxigenin-UTP for the GnRH cRNA probe cannot be derived, a test in situ hybridization was performed to determine empirically the optimal concentration for this probe.

\section{Single label in situ hybridization for GnRH mRNA}

Using the probe complimentary to GnRH mRNA, we performed single label in situ hybridization, as previously described $(8,33)$. Briefly, sections were fixed in $4 \%$ paraformaldehyde and treated with $0.25 \%$ acetic anhydride in $0.1 \mathrm{M}$ triethanolamine for $10 \mathrm{~min}$. The slides were rinsed in $2 \times \mathrm{SSC}(1 \times \mathrm{SSC}=150 \mathrm{~mm} \mathrm{NaCl}$ and $15 \mathrm{~mm} \mathrm{Na}$ citrate $)$, dehydrated in a series of alcohols, delipidated in chloroform, and rehydrated in a second series of alcohols. The GnRH cRNA probe was diluted in hybridization buffer and placed onto each slide $(60 \mu \mathrm{l} / \mathrm{slide})$ Individual slides were covered with parafilm, sealed with rubber cement, and incubated overnight in moist chambers at $60 \mathrm{C}$. On the following day, the slides received RNAse-A treatment and a series of salt washes of increasing stringency. The slides were dehydrated in alcohols and air dried. 


\section{Autoradiography and histological staining of single label slides}

Slides were dipped in Kodak NTB-2 emulsion (42 C; Eastman Kodak, Rochester, NY) diluted 1:1 with $600 \mathrm{~mm}$ ammonium acetate. The tissuc sections were allowed to air dry for $2 \mathrm{~h}$ and then stored with desiccant in light-tight boxes at $4 \mathrm{C}$ for 4 days $(\operatorname{Exp} 3)$. The slides were developed in Kudak D-19 developer and counterstained with cresyl violet before application of coverslips.

\section{Double label in situ hybridization for GnRH $m R N A$ and galanin $m R N A$}

We performed a double label in situ hybridization to identify cells containing both GnRH mRNA and galanin mRNA following a protocol that was similar to that described for the single label in situ hybridization. The galanin ${ }^{35} \mathrm{~S}$-labeled probe was mixed with the digoxigenin-labeled GnRH cRNA probe in hybridization buffer. After the stringent washes of the second day, the slides were placed in $2 \times$ SSC and $0.05 \%$ Triton $X-100$ containing $2 \%$ normal sheep serum for $30 \mathrm{~min}$. The slides were washed in buffer $1(100 \mathrm{~mm}$ Tris-HCl, $\mathrm{pH} 7.5$, and $150 \mathrm{~mm} \mathrm{NaCl})$, then incubated for $3 \mathrm{~h}$ at $37 \mathrm{C}$ with antidigoxigenin antibody fragments conjugated to alkaline phosphatase (Boehringer Mannheim) diluted 1:1000 in buffer 1 containing 1\% normal sheep scrum and $0.3 \%$ Triton $X-100$. The slides were washed and incubated in a chromagen solution for $4 \mathrm{~h}$ at $37 \mathrm{C}$. The reaction was stopped, and the slides were air dried. Before being dipped in emulsion, the slides were dipped in $3 \%$ parlodion (Fisher Scientific, Fair Lawn, NJ) dissolved in isoamyl acetate. For double label analysis, 8 days of exposure (Exp 1, 2, and 4) were allowed for visualization of silver grain clusters representing galanin mRNA-positive cell bodies.

\section{Semiquantitative analysis of cellular $m R N A$}

Tissue sections were viewed under a Zeiss Axioskop (Zeiss, New York, NY) equipped with a $\times 40$ epiillumination darkfield objective. We determined the number of silver grains per cell using a grain-counting program, as previously described $(8,34)$. This system consisted of a PixelGrabber video acquisition board (Perceptics Corp., Knoxville, TN) attached to a Macintosh IIfx computer (Apple Computer Corp., Cupertino, CA). Video images were obtained by a Dage model 65 camera (Dage-MTI, Inc., Michigan City, IN) attached to the Zeiss Axioskop.

To estimate the level of galanin mRNA expression in each GnRH neuron, a purple-stained digoxigenin-labeled GnRH mRNA-containing cell was first isolated under brightfield illumination. The silver grains overlying each cell were then visualized and counted under darkfield epillumination by the image analyzer. Seventeen tissue sections per animal, equally spaced throughout the diagonal band of Broca and preoptic area, with the most caudal slice at the level of the suprachiasmatic nucleus and the rostral aspect of the lateral hypothalamus, were analyzed for the number of grains per cell, representing the relative galanin mRNA content in GnRH neurons. Areas examined for cellular galanin mRNA content in single labeled cells included the preoptic area, the diagonal band of Broca, the bed nucleus of the stria terminalis, the supraoptic nucleus, and the median preoptic nucleus. In all experiments, the sections were anatomically matched between groups, and the analysis was performed by an operator unaware of the animal's experimental group.

GnRH cells were identified under brightfield illumination by the presence of a dark purple-stained cell body, as previously described (8). To avoid the subjective decision of whether a GnRH neuron was double labeled, all GnRH neurons were analyzed for galanin mRNA content by grain count measurements. If it were true that only some $\mathrm{GnRH}$ neurons express galanin mRNA, then the estimates we derived for galanin mRNA content in the entire population would underestimate the true values of the subset that do, in fact, express galanin mRNA. Single labeled galanin neurons (without purple-stained cell bodies) were identified by the presence of a discrete grain cluster, as previously described $(8,34)$, and these grain counts were used to derive estimates of galanin mRNA content in this population. Because the selection criteria for this population may eliminate cells expressing galanin mRNA at low levels, the galanin mRNA signal levels we report will have overestimated their true value. The difference between reading grain counts over all digoxigeninlabeled cells, on the one hand, and reading grain counts in identified grain clusters, on the other hand, make it appear that GnRH neurons expressing galanin mRNA do so at lower levels than non-GnRH-expressing galanin neurons (compare mean grain counts between Fig. 1, $A$ and $B$ ). Therefore, this approach does not allow us to determine whether this difference is real or artifactual.

\section{Slatislical analysis}

For all experiments, $\mathrm{n}$ refers to the number of experimental animals within a group, and this was the $\mathrm{n}$ used in the analysis. For cellular GnRH or galanin mRNA content determinations, the mean grains per cell from individual animals (and anatomical areas within animals) were used to calculate the mean \pm SEM for each group. In each experiment, the differences between groups were assessed by analysis of variance (ANOVA). The rejection level for statistical tests was set at $\alpha=0.05$. When the ANOVA indicated a significant difference between groups within an experiment, Student's $t$ test was used to analyze differences between pairs of groups.

\section{Control experiments}

Control experiments were performed to assess the specific tissue binding of the galanin cRNA probe and both types of GnRH cRNA probes, as described previously $(8,33)$. The control experiments included pretreatment of tissue with RNAse before performing in situ hybridization, hybridization with a labeled sense probe, and incubation with a 100 -fold greater concentration of unlabeled antisense probe in the presence of ${ }^{35} \mathrm{~S}$-labeled antisense probe. The tissue was processed for hybridization histochemistry, as described above. Both experiments resulted in complete loss of specific labeling, as evidenced by a lack of either photographic grain clusters in tissues incubated with the ${ }^{35} \mathrm{~S}$ labeled probes or purple-stained cells in tissues incubated with the digoxigenin probe (data not shown).

\section{Serum LH and $17 \beta$-estradiol determination}

Serum LH and $17 \beta$-estradiol levels were measured by RIA in the laboratory of Dr. David L. Hess (Division of Reproductive Biology and Behavior, Oregon Regional Primate Research Center, Beaverton, OR). LH was measured by a double antibody RI $\Lambda$ with reagents obtained from the National Hormone and Pituitary Program. Estradiol was measured by RIA after chromatography of the plasma samples, as described by Guodman (35). The intraassay coefficients of variation were $6.4 \%$ and $6.9 \%$ for the LH and $17 \beta$-estradiol assays, respectively.

\section{Results}

\section{Hormone levels}

The results presented in Table 1 reflect the fact that each of the animals in Exp 1-3 had a distinct LH surge on the day of proestrus. In Exp 4, the OVX sham-treated animals had negligible levels of plasma estradiol, while the diestrus 1 and

TABLE 1. Plasma levels of $\mathrm{LH}$ and estradiol in all experimental groups

\begin{tabular}{lcc}
\hline \multicolumn{1}{c}{ Group } & L.H $(\mathrm{ng} / \mathrm{ml})$ & Estradiol $(\mathrm{pg} / \mathrm{ml})$ \\
\hline Proestrus, $1200 \mathrm{~h}$ & $35 \pm 5$ & $\mathrm{NA}^{a}$ \\
Proestrus, $1800 \mathrm{~h}$ & $1934 \pm 165$ & $\mathrm{NA}$ \\
Estrus, $1800 \mathrm{~h}$ & $24 \pm 7$ & $\mathrm{NA}$ \\
Diestrus, $1000 \mathrm{~h}$ & $24 \pm 2$ & $\mathrm{NA}$ \\
Diestrus, $1800 \mathrm{~h}$ & $67 \pm 15$ & $14 \pm 6$ \\
OVX & $2000 \pm 290$ & $0.7 \pm 0.5$ \\
OVX + E & $17 \pm 1$ & $50 \pm 13$ \\
\hline
\end{tabular}

Values are the mean \pm SEM. NA, Not assayed. 
OVX plus estrogen replacement animals had $17 \beta$-estradiol levels in the moderate and high physiological range, respectively (Table 1 ).

\section{Galanin mRNA content in GnRH neurons during the estrous cycle}

Exp 1. Animals killed at $1800 \mathrm{~h}$ on the day of proestrus had greater than 2-fold higher galanin mRNA signal levels in $\mathrm{GnRH}$ neurons than those killed at $1200 \mathrm{~h}$ on proestrus $(1200 \mathrm{~h}, 29.7 \pm 7.7 ; 1800 \mathrm{~h}, 69.3 \pm 13.9$ grains/cell; $P<$ 0.02 ; Fig. 1A). The animals killed at $1800 \mathrm{~h}$ on estrus had galanin mRNA signal levels not significantly different from those found at $1800 \mathrm{~h}$ on proestrus (estrus, $1800 \mathrm{~h}, 66.3 \pm$ 5.3 ; proestrus, $1800 \mathrm{~h}, 69.3 \pm 13.9$ grains/cell; $P>0.80$; Fig. 1A). In non-GnRH galanin neurons, there was no significant difference in cellular galanin mRNA signal content among groups (proestrus, $1200 \mathrm{~h}, 145.7 \pm 13.9$; proestrus, $1800 \mathrm{~h}$,

\section{A}

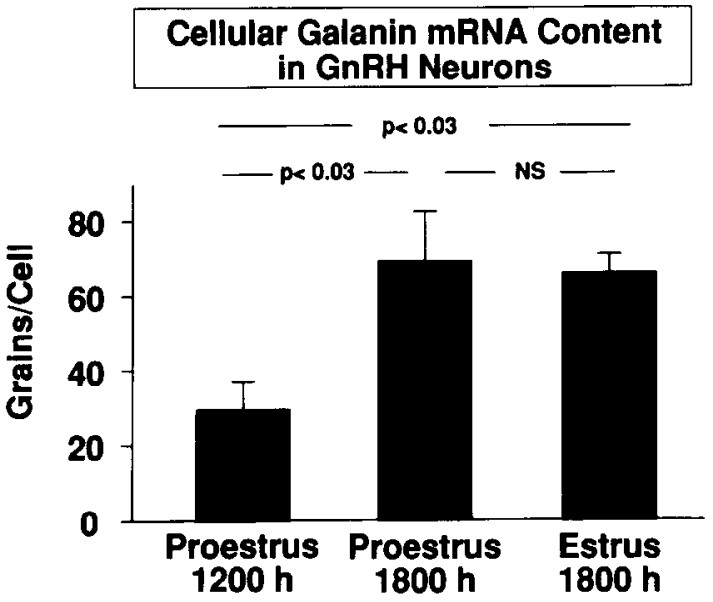

B

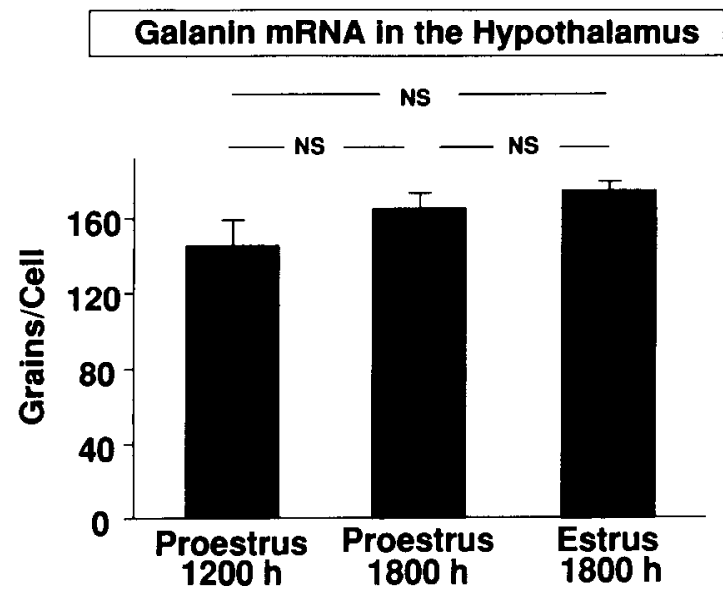

FIG. 1. A, Comparison among adult female rats, at 3 time points during the estrous cycle, of galanin mRNA signal levels (grains per cell \pm SEM) in GnRH mRNA-positive cells throughout the forebrain and rostral hypothalamus. In each case, 3 animals were examined, with 15 sections/animal. B, Comparison among adult female rats, at three time points during the estrous cycle, of galanin mRNA signal levels (grains per cell \pm SEM) in non-(-GRRH neurons throughout the forebrain and rostral hypothalamus.
$165.8 \pm 9.1$; estrus, $1800 \mathrm{~h}, 175.3 \pm 5.9$ grains $/$ cell; $P>0.70$; Fig. 1B). There was no significant difference among groups in the total number of GnRH neurons counted (proestrus, $1200 \mathrm{~h}, 77 \pm 26$; proestrus, $1800 \mathrm{~h}, 82 \pm 3$; estrus, $1800 \mathrm{~h}$, $76 \pm 19 ; P>0.70$, by ANOVA; data not shown). Simultaneous bright- and darkfield images of representative cells from this experiment are shown in Fig. 2.

Exp 2. In this experiment, we confirmed the results of Exp 1 and found that animals killed at $1800 \mathrm{~h}$ on the day of proestrus had 1.6-fold higher galanin mRNA signal levels in GnRH neurons than those killed at $1200 \mathrm{~h}$ on proestrus $(1200 \mathrm{~h}, 23.2 \pm 4.2 ; 1800 \mathrm{~h}, 37.9 \pm 2.6$ grains/cell; $P<0.02$; Fig. 3). The animals killed at $1800 \mathrm{~h}$ on estrus had signal levels not significantly different from those found at $1800 \mathrm{~h}$ on proestrus (estrus, $1800 \mathrm{~h}, 45.6 \pm 5.2$; proestrus, $1800 \mathrm{~h}$, $37.9 \pm 2.6$ grains/cell; $P=0.13$ ). Animals killed at $1000 \mathrm{~h}$ on diestrus 1 had galanin mRNA signal levels $(22.5 \pm 2.9$ grains/cell) that were not different from those at $1200 \mathrm{~h}$ on proestrus, but were significantly lower than the levels at $1800 \mathrm{~h}$ on proestrus and $1800 \mathrm{~h}$ on estrus $(P<0.02$, by ANOVA). There was no difference between groups in the total number of GnRH neurons counted (proestrus, $1200 \mathrm{~h}$, $88 \pm 14$; proestrus, $1800 \mathrm{~h}, 66 \pm 5$; estrus, $1800 \mathrm{~h}, 86 \pm 14$; diestrus, $1000 \mathrm{~h}, 61 \pm 8 ; P>0.20$, by ANOVA; data not shown).

\section{GnRH mRNA content across the estrous cycle}

Exp 3. We observed no significant difference among groups in either cellular levels of GnRH mRNA signal (proestrus, $1200 \mathrm{~h}, 179 \pm 12$; proestrus, $1800 \mathrm{~h}, 180 \pm 8$; estrus, 1800 h, $177 \pm 20$ grains/cell; Fig. $4 \mathrm{~A}$ ) or the number of $\mathrm{GnRH}$ mRNA-containing neurons (proestrus, $1200 \mathrm{~h}, 165 \pm 31$; proestrus, $1800 \mathrm{~h}, 171 \pm 25$; estrus, $1800 \mathrm{~h}, 188 \pm 10$ total cells; Fig. 4B). There was no significant difference in either the number of GnRH neurons or the cellular content of GnRH mRNA across anatomical areas (data not shown).

Exp 4. Long term (21-day) OVX rats killed at $1800 \mathrm{~h}$ had grain counts that were $31 \%$ of those in the intact cycling female animals killed at $1800 \mathrm{~h}$ on diestrus 1 (diestrus, $21 \pm$ 4; OVX, $6.6 \pm 0.5$ grains/cell; $P<0.006$; Fig. 5). This decline in galanin mRNA content in OVX animals was completely reversed in animals given $17 \beta$-estradiol implants immediately after ovariectomy (OVX $+\mathrm{E}, 27 \pm 5$; OVX, $6.6 \pm 0.5$ grains/cell; $P=0.0007 ;$ Fig. 5). Intact (diestrous) females had grain counts representing galanin mRNA content in GnRH neurons that were not statistically different from those in the OVX + E females (OVX + E, $27 \pm 5$; diestrus 1, $21 \pm 4$ grains/cell; $P>0.3$; Fig. 5).

\section{Discussion}

We report that galanin mRNA content in GnRH neurons varies during the estrous cycle in the rat. The day of proestrus is punctuated by a large increase in galanin mRNA content in GnRH neurons between 1200-1800 h. Relatively high levels of galanin mRNA are maintained for at least $24 \mathrm{~h}$ (until $1800 \mathrm{~h}$ on estrus), but return to nadir levels within 42 

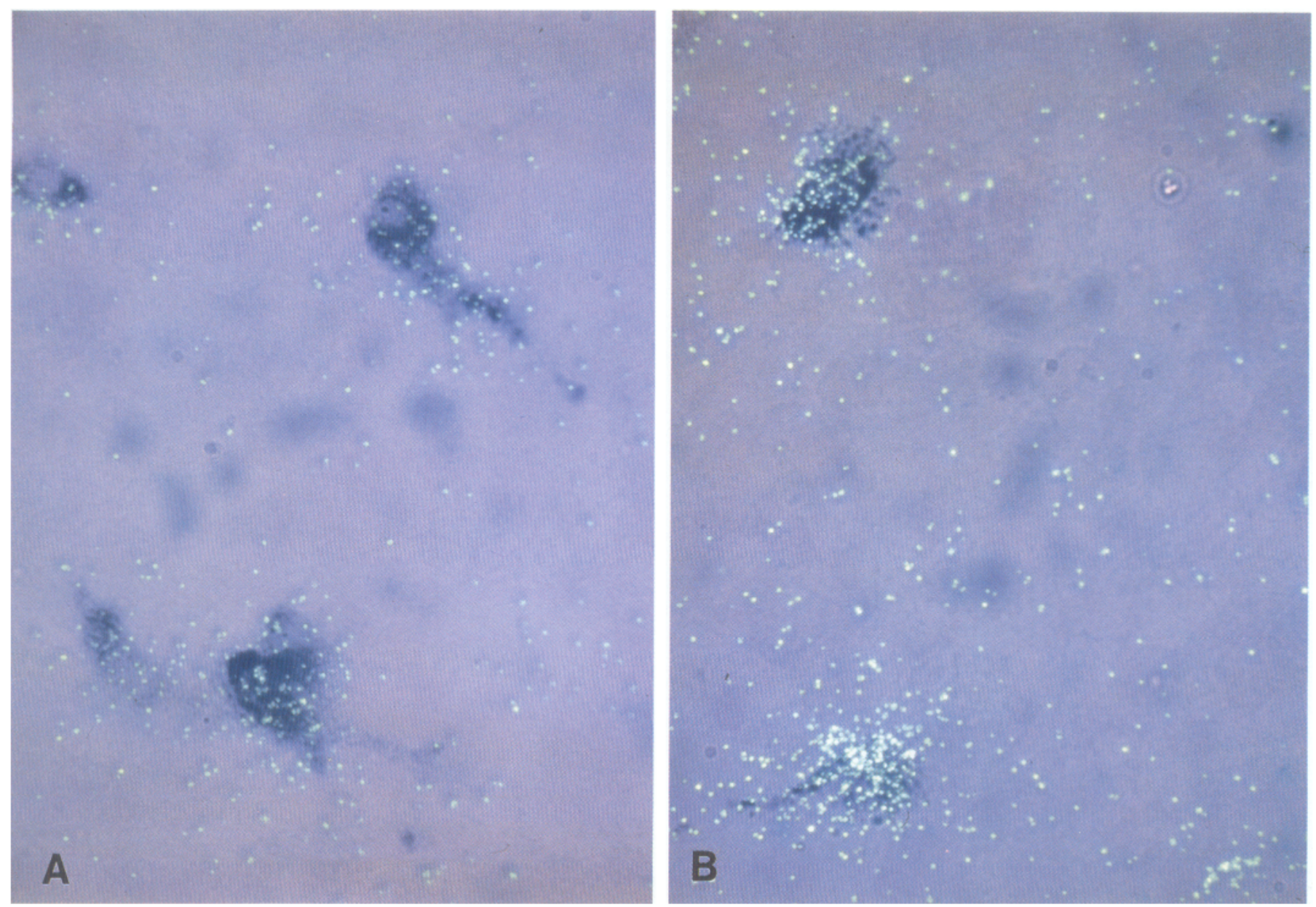

FIG. 2. Simultaneous bright- and darkfield photomicrographs of the medial preoptic area of adult female rats, showing cells labeled with a digoxigenin-conjugated cRNA probe for $\mathrm{GnRH}$ mRNA and a cRNA probe for galanin mRNA labeled with ${ }^{35} \mathrm{~S}$ in sections obtained from animals killed at $1200 \mathrm{~h}$ (left panel) and $1800 \mathrm{~h}$ (right panel) on the day of proestrus.

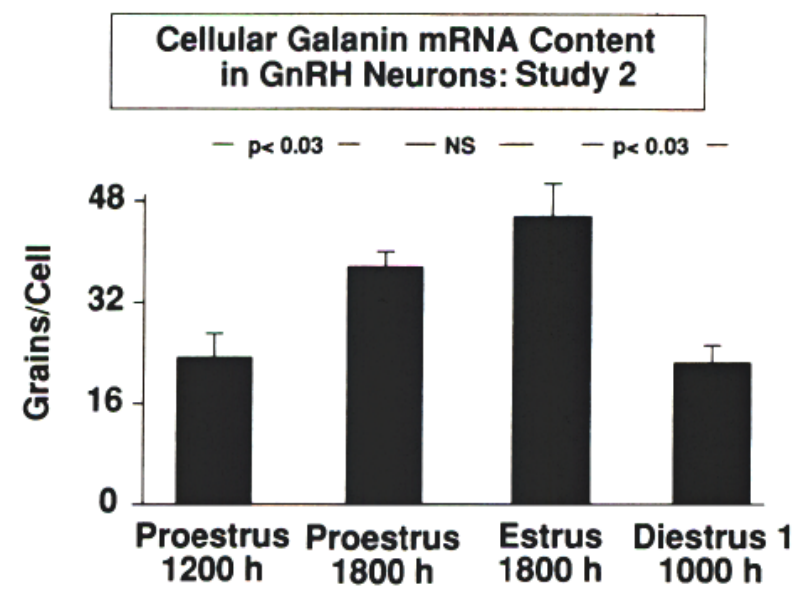

FIG. 3. Comparison among adult female rats, at four time points during the estrous cycle, of galanin mRNA signal levels (grains per cell \pm SEM) in GnRH mRNA-positive cells throughout the forebrain and rostral hypothalamus.

$\mathrm{h}$ after the proestrous rise $(1000 \mathrm{~h}$ on diestrus 1$)$. These observations indicate that the increased levels of galanin peptide in $\mathrm{GnRH}$ neurons observed on proestrus by Merchenthaler and his colleagues $(7,36)$ is due to a stimulation of galanin gene expression and biosynthesis, rather than a decrease in axonal transport and release of the peptide. Moreover, we have demonstrated that the induction of the galanin gene in GnRH neurons is both robust and rapid, with the galanin mRNA signal increasing 2 -fold in $6 \mathrm{~h}$. The induction of galanin mRNA levels at proestrus appears to be restricted to GnRH neurons, since analysis of a large sample of galanin mRNA-containing neurons that did not colabel for $\mathrm{GnRH}$ revealed no changes in galanin mRNA content during the estrous cycle. Thus, the regulation of galanin expression by ovarian steroids in this defined subpopulation highlights the heterogeneous nature of the galanin neuronal population in the hypothalamus and strengthens the hypothesis that galanin is involved in the regulation of gonadotropin release.

The increase in galanin mRNA expression in GnRH neurons occurs during a period of activation of these cells. The proestrous surge in gonadotropin release is preceded by an increase in GnRH release into the portal vessels (37). This 
A

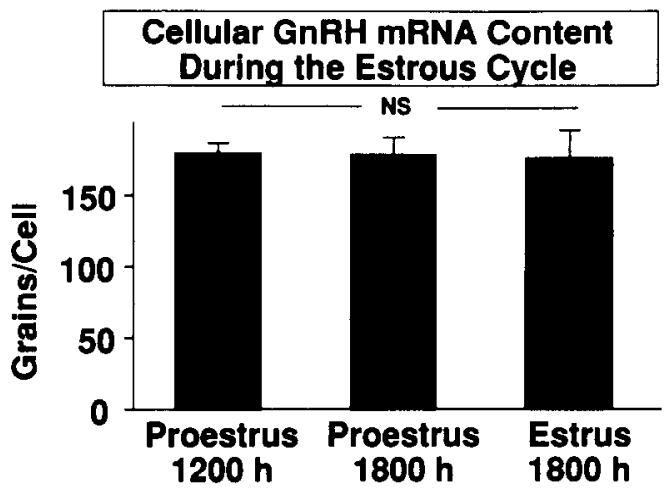

B

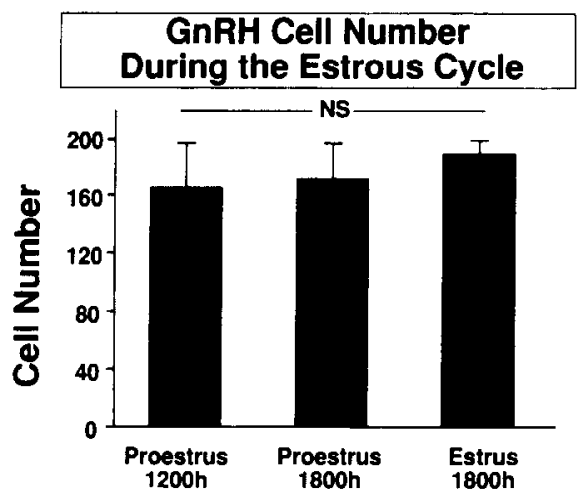

FIG. 4. A, Comparison among adult female rats, at three time points during the estrous cycle, of GnRH mRNA signal levels (grains per cell \pm SEM) in labeled cells throughout the forebrain and rostral hypothalamus. B, Comparison among adult female rats, at three time points during the estrous cycle, of the relative number of $\mathrm{GnRH}$ mRNApositive neurons (mean \pm SEM) in labeled cells throughout the forebrain and rostral hypothalamus.

increase in $\mathrm{GnRH}$ release at proestrus may be facilitated by galanin acting through receptors in the median eminence (6). Indeed, galanin peptide enhances GnRH release from the median eminence in vitro in a dose-dependent manner (38), and galanin is found in relatively high concentrations in the portal plasma (4). This suggests that corelease of galanin from GnRH neurons could elevate the concentration of galanin in the vicinity of GnRH nerve terminals and thereby facilitate GnRH release. For maximal GnRH secretion at the midcycle surge, the GnRH neurons coexpressing galanin would, in theory, be those that are activated at proestrus and contribute to the generation of the LH surge. The pattern of GnRH neurons colocalizing galanin peptide (7) and its coding mRNA (8) is strikingly similar to the distribution of $\mathrm{GnRH}$ neurons activated during the proestrous LH surge $(15,20)$. The increase in galanin mRNA is largely confined to cells in more caudal sections (data not shown), correlating with areas where steroid-induced induction of c-fos and c-jun in $\mathrm{GnRH}$ neurons occurs $(15-17,20)$. The expression of the c-fos gene is considered an indicator of neuronal activation (18-20), and it is tempting to speculate that the population of GnRH neurons activated during proestrus is that which coexpress

\section{Cellular Galanin mRNA content in GnRH Neurons}

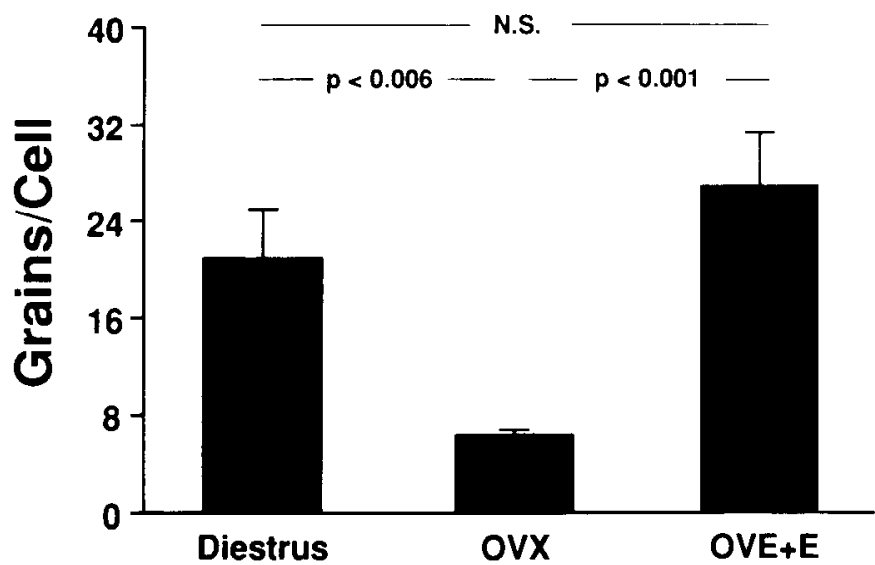

FIG. 5. Comparison, between intact OVX and OVX plus estradiolreplaced $(\mathrm{OVX}+\mathrm{E})$ female rats, of galanin mRNA signal levels (grains per cell \pm SEM) in GnRH mRNA-positive cells throughout the forebrain and rostral hypothalamus.

galanin mRNA and respond to galanin stimulation. This model predicts a self-stimulatory feedback loop that amplifies $\mathrm{GnRH}$ release during the proestrous surge.

One of the earliest detectable events on the day of proestrus is a dramatic rise in plasma estrogen levels. The increasing estrogen level acts as a feedback signal to the hypothalamus, where it may regulate $\mathrm{GnRH}$ release through a number of mechanisms. The importance of this feedback in the generation of the preovulatory surge in gonadotropins is demonstrated by studies of OVX rats in which a pharmacologically induced increase in plasma estrogen produces a surge-like release of LII (39). Although the regulation of LH release by estrogen is complex, GnRH neurons provide the final signal from the hypothalamus to the pituitary gonadotropes. Galanin may be uniquely suited to provide a direct estrogen-sensitive response within $\mathrm{GnRH}$ neurons that regulates their interaction with the pituitary. In this report, we have shown that a reduction of circulating estrogen levels is associated with a diminution of galanin mRNA levels in GnRH neurons and, conversely, that estrogen induces galanin gene expression in these same GnRH cells. The diminished grain counts in the OVX animals reflect the fact that grains were counted over all $\mathrm{GnRH}$ neurons and that very few $(\sim 10 \%)$ appeared to be unambiguously double labeled, whereas in the intact and estradiol-replaced animals, most GnRH neurons ( $-65 \%)$ were double labeled. The finding that the animals with estrogen implants did not have significantly higher levels of galanin mRNA in GnRH neurons relative to the intact females, despite having much higher levels of plasma estradiol, indicates that other factors, such as progesterone, may be required to obtain maximal induction of galanin mRNA in GnRH neurons. Alternatively, these results may reflect the difference between estradiol treatment for 21 days and the fluctuating levels of estradiol occurring over the estrous cycle.

Although estrogen influences total galanin mRNA levels 
in the pituitary (40), it does not affect the overall levels in the hypothalamus $(40,41)$. However, we have shown that a subset of hypothalamic galanin neurons, i.e. GnRH neurons, appears to be regulated as a function of the plasma estrogen concentration. Again, these ubservations emphasize the physiological heterogeneity among the population of galanin neurons in the hypothalamus and support the concept that populations of galanin neurons located within positionally defined nuclei may serve a variety of physiological functions and respond to a variety of physiological stimuli. We hypothesize that the rising tide of plasma estrogen observed early in proestrus stimulates galanin mRNA expression and biosynthesis in GnRH neurons, thereby replenishing the releasable pool of galanin peptide depleted during the proestrous surge. Similar to the regulation of cFos expression (16), progesterone may also play a role in determining the level of induction of galanin mRNA in these cells. It is conceivable, for example, that estrogen is responsible for maintaining a basal level of galanin expression, as found during diestrus 1 , and that progesterone is responsible for the rapid induction of galanin mRNA levels observed on proestrus. GnRH neurons are not thought to express estrogen receptors and apparently do not concentrate estradiol (42). Although these observations would suggest that GnRH neurons are not themselves the target of estrogen action, the issue may warrant careful reconsideration with more sensitive technology. It would seem, therefore, more plausible that the induction of galanin mRNA in GnRH neurons by estradiol is mediated indirectly, via other neuronal systems. For example, the effects of estradiol may be mediated by neurotensin neurons and their interaction with GnRH neurons $(43,44)$. Alternatively, the GnRH neuron may itself be responsive to steroid hormones through a nontraditional pathway, such as a cell surface steroid receptor (45-47). In the case of either direct or indirect signaling to the GnRH neuron, the final common pathway of estrogen action may involve induction of cFos or cJun expression in GnRH neurons, which, in turn, alters the expression of the galanin gene in these cells. Indeed, the $5^{\prime}-$ flanking region of the rat galanin gene is known to contain the AP-1 site required for transcriptional regulation by the Fos protein (48), and preliminary evidence suggests that the action of estradiol to induce galanin gene expression in the pituitary involves a requisite induction of cFos (49).

It is conceivable that the induction of galanin mRNA in GnRH neurons that we observed on proestrus actually reflects the occurrence of a circadian event triggered in $\mathrm{GnRH}$ neurons every day of the cycle. Arguing in favor of this possibility is the fact that the LH surge itself is tightly coupled to a circadian oscillator, the activity of which can be revealed by constant exposure to estradiol (39). Arguing against the likelihood of this being a circadian phenomenon is the fact that during the estrous cycle, expression of Fos protein in $\mathrm{GnRH}$ neurons is limited to the afternoon of proestrus (15). Given that the galanin gene has an AP-1 site (48), we infer that induction of galanin mRNA in GnRH neurons is mediated through the immediate-early gene, cFos. Proof that induction of galanin mRNA in GnRH neurons is linked to the LH surge itself and is dissociated from the circadian rhythm generator must await a critical test of this hypothesis. The observation demonstrating the regulation of galanin mRNA in GnRH neurons contrasts with our findings related to cellular GnRH mRNA levels. In this case, we have shown that neither the number of cells expressing GnRH mRNA nor the content of GnRH mRNA in individual neurons changes during the three estrous cycle stages examined. Our results are in full accord with those of Malik (21) et al., but are discordant with the findings of Park et al. (23) and Zoeller and Young (22), who report that GnRH mRNA levels appear to vary across the estrous cycle. Although the studies of Park and Zoeller are themselves conflicting on several points, each testifies to a significant increase in GnRH mRNA on the afternoon compared with the morning of procstrus. Our own laboratory has shown changes in a number of other neuropeptide mRNAs in response to steroid manipulation, including GH-releasing hormone (50), somatostatin (51), POMC (52), and galanin. On the other hand, the use of identical experimental paradigms to study the regulation of the $\mathrm{GnRH}$ gene has shown that its expression is unaffected by dramatic changes in the steroidal milieu (Refs. 33 and 53 and the present study). In any case, the data presented here indicate that any changes in cellular content of GnRH mRNA are small relative to the changes in galanin $\mathrm{mRNA}$ in these same cells. It is conceivable that there are other peptides, receptors, or enzymes in $\mathrm{GnRH}$ neurons that are also sensitive to steroid levels, thereby providing a multifaceted response to gonadal feedback.

In summary, we have shown that expression of the galanin gene in GnRH neurons varies markedly across the estrous cycle and is induced by estrogen. Although the physiological significance of changes in galanin gene expression in GnRH neurons remains unknown, the available experimental data suggest that galanin plays an important role in the regulation of gonadotropin secretion. Based on the finding that the pattern of colocalization is sexually dimorphic, with much greater galanin expression in the GnRH neurons of females compared to males $(7,8)$, we would infer that galanin's role may be most important in processes unique to the female, such as ovulation.

\section{Acknowledgments}

The authors thank Emilia Kabigting, Alexandru Bageac, and Beth Tiemens for their excellent technical assistance. We are also indebted to Dr. David Hess for supervising the hormone analyses, which were conducted at the Oregon Regional Primate Research Center (Beaverton, OR).

\section{References}

1. Tatemoto K, Rokaeus A, Jorwall H, McDonald TJ, Mutt V 1983 Galanin: a novel biologically active peptide from porcine intestine. FEBS Lett 164:124-128

2. Vrontakis ME, Peden LM, Duckworth ML, Friesen HG 1987 Isolation and characterization of a complimentary DNA (galanin) clone from estrogen-induced pituitary tumor messenger RNA. J Biol Chem 262:16755-16758

3. Ottletcz A, Snyder GD, McCann SM 1988 Regulatory role of galanin on control of hypothalamic-anterior pituitary function. Proc Natl Acad Sci USA 85:9861-9865 
4. López FJ, Merchenthaler I, Ching M, Wisniewski G, Negro-Vilar A 1991 Galanin: a hypothalamic-hypophysiotropic hormone modulating reproductive functions. Proc Natl Acad Sci USA 88:45084512

5. Sahu A, Crowley WR, Tatemoto K, Balasubramaniam A, Kalra S 1987 Effects of neuropeptide Y, NPY analog (norleucine-NPY), galanin and neuropeptide $\mathrm{K}$ on $\mathrm{LH}$ release in ovariectomized (OVX) and OVX estrogen, progesterone treated rats. Peptides 8:921-926

6. Melander T, Köhler C, Nilsson S, Hökfelt T, Brodin E, Theodorsson E, Bartfai T 1988 Autoradiographic quantitation and anatomical mapping of ${ }^{125} \mathrm{I}$-Galanin binding sites in the rat central nervous system. J Chem Neuroanat 1:213-233

7. Merchenthaler I, López FJ, Lennard DE, Negro-Vilar A 1991 Sexual differences in the distribution of neurons coexpressing galanin and luteinizing hormone-releasing hormone in the rat brain. Endocrinology 129:1977-1986

8. Marks DL, Wiemann JN, Burton KA, Lent KL, Clifton DK, Steiner RA 1992 Simultaneous visualization of two cellular mRNA species in individual neurons by use of a new double in situ hybridization method. Mol Cell Neurosci 3:395-405

9. Schally AV, Arimura A, Baba Y, Nair RMG, Matsuo H, Redding TW, Debeljuk L 1971 Isolation and properties of the FSH and LHreleasing hormone. Biochem Biophys Res Commun 43:393-397

10. Schally AV, Arimura A, Kastin AJ, Matsuo H, Baba Y, Redding TW, Nair RMG, Debeljuk L 1971 Gonadotropin-releasing hormone: one polypeptide regulates secretion of luteinizing and folliclestimulating hormone. Science 173:1036-1037

11. Simard J, Labrie C, Hubert JF, Labrie F 1988 Modulation by sex steroids and $\left[\mathrm{D}-\operatorname{Trp}^{6}\right.$, Des-Gly- $\left.\mathrm{NH}_{2}{ }^{10}\right]$ luteinizing hormone $(\mathrm{LH})$-re leasing hormone of alpha-subunit and LH beta messenger ribonucleic acid levels in the rat anterior pituitary gland. Mol Endocrinol 2:775-784

12. Fox SR, Smith MS 1958 Changes in the pulsatile pattern of luteinizing hormone secretion during the rat estrous cycle. Fndocrinology 116:1485-1492

13. Gay VL, Midgely ARJ 1969 Response of the aduit rat to orchidectomy and ovariectomy as determined by radioimmunoassay. Endocrinology 84:1359-1364

14. Butcher RL, Collins WE, Fugo NW 1974 Plasma concentration of LH, FSH, prolactin, progesterone, and estradiol 17 beta throughout the 4-day estrous cycle of the rat. Endocrinology 94:1704-1708

15. Lee W-S, Smith MS, Hoffman GE 1990 Luteinizing hormonereleasing hormone neurons express fos protein during the proestrous surge of luteinizing hormone. Proc Natl Acad Sci USA 87:51635167

16. Lee WS, Smith MS, Hoffman GE 1990 Progesterone enhances the surge of luteinizing hormone by increasing the activation of luteinizing hormone-releasing hormone neurons. Endocrinology 127:2604-2606

17. Lee WS, Abbud R, Smith MS, Hoffman GE 1992 LHRH neurons express cJUN protein during the proestrous surge of luteinizing hormone. Endocrinology 130:3101-3103

18. Sagar SM, Sharp FR, Curran T 1988 Expression of c-fos protein in brain: metabolic mapping at the cellular level. Science 240:13281331

19. Hunt S, Pini A, Evan G 1987 Induction of c-fos-like protein in spinal cord neurons following sensory stimulation. Nature 328:632634

20. Lee WS, Smith MS, Hoffman GE 1992 cFos activity identifies recruitment of luteinizing hormone releasing hormone neurons during the ascending phase of the proestrous luteinizing hormone surge. J Neuroendocrinol 4:161-166

21. Malik KF, Silverman AI, Morrell JI 1991 Gonadotropin-releasing hormone mRNA in the rat: distribution and neuronal content over the estrous cycle and after castration of males. Anat Rec 231:457466

22. Zoeller RT, Young WS 1988 Changes in cellular levels of messenger ribonucleic acid encoding gonadotropin releasing hormone in the anterior hypothalamus of female rats during the estrous cycle. Endocrinology 123:1688-1689

23. Park O, Gugneja S, Mayo KE 1990 Gonadotropin-releasing hormone gene expression during the rat estrous cycle: effects of pen- tobarbital and ovarian steroids. Endocrinology 127:365-372

24. Zoeller RT, Seeburg PH, Young WS 1988 In situ hybridization histochemistry for messenger ribonucleic acid (mRNA) encoding gonadotropin releasing hormone ( $\mathrm{GnRH})$ : effect of estrogen on cellular levels of GnRH mRNA in female rat brain. Endocrinology $122: 2570-2577$

25. Toranzo D, Dupont E, Simard J, Labrie C, Couet J, Labrie F, Pelletier G 1989 Regulation of pro-gonadotropin-releasing hormone gene expression by sex steroids in the brain of male and female rats. Mol Endocrinol 3:1748-1756

26. Wray S, Zoeller RT, Gainer H 1989 Differential effects of estrogen on luteinizing hormone-releasing hormone gene expression in slice explant cultures prepared from specific rat forebrain regions. $\mathrm{Mol}$ Endocrinol 3:1197-1206

27. Roberts JL, Dutlow CM, Jakubowski M, Blum M, Millar RP 1989 Estradiol stimulates preoptic area-anterior hypothalamic proGnRHGAP gene expression in ovariectomized rats. Mol Brain Res 6:127134

28. Kim K, Lee BJ, Park Y, Cho WK 1989 Progesterone increases messenger ribonucleic acid (mRNA) encoding luteinizing hormone releasing hormone (LHRH) level in the hypothalamus of ovariectomized estradiol-primed prepubertal rats. Mol Brain Res 6:151-158

29. Rothfeld J, Hejtmancik JF, Conn PM, Pfaff DW 1989 In situ hybridization for LHRH mRNA following estrogen treatment. Mol Brain Res 6:121-125

30. Paxinos G, Watson C 1982 The Rat Brain in Stereotaxic Coordinates. Academic Press, New York

31. Adelman JP, Mason AJ, Hayflick JS, Seeburg PH 1986 Isolation of the gene and hypothalamic cDNA for the common precursor of gonadotropin-releasing hormone and prolactin release inhibiting factor in human and rat. Proc Natl Acad Sci USA 83:179-183

32. Rogers KV, Vician L, Steiner RA, Clifton DK 1988 The effect of hypophysectomy and growth hormone administration on preprosomatostatin messenger ribonucleic acid in the periventricular nucleus of the rat hypothalamus. Endocrinology 122:586-589

33. Wiemann JN, Clifton DK, Steiner RA 1990 Gonadotropin releasing hormone messenger ribonucleic acid levels are unaltered with changes in the gonadal hormone milieu of the adult male rat. Endocrinology 127:523-532

34. Chowen JA, Steiner RA, Clifton DK 1991 Semiquantitative analysis of cellular somatostatin mRNA levels by in situ hybridization histochemistry. In: Conn PM (ed) Methods in Neurosciences. Academic Press, San Diego, vol 5:137-158

35. Goodman RL 1978 A quantitative analysis of the physiological role of estradiol and progesterone in the control of tonic and surge secretion of luteinizing hormone in the rat. Endocrinology 102:142150

36. Merchenthaler I, Sex linked differences in galanin and LHRH coexpression in preoptic-septal neurons are enhanced by estrogen 73rd Annual Meeting of The Endocrine Society, Washington DC, 1991 (Abstract 1715)

37. Sarkar DK, Chiappa SA, Fink G, Sherwood NM 1976 Gonadotropin-releasing hormone surge in pro-oestrous rats. Nature 264:461463

38. Merchenthaler I, Lopez FJ, Negro-Vilar A 1990 Colocalization of galanin and luteinizing hormone-releasing hormone in a subset of preoptic hypothalamic neurons: anatomical and functional correlates. Proc Natl Acad Sci USA 87:6326-6330

39. Legan SJ, Coon GA, Karsch FJ 1975 Role of estrogen as initiator of daily LH surges in the ovariectomized rat. Endocrinology 96:50-62

40. Kaplan LM, Gabriel SM, Koenig JI, Sunday ME, Spindel ER, Martin JB, Chin WW 1988 Galanin is an estrogen-inducible, secretory product of the anterior pituitary. Proc Natl Acad Sci USA $85: 17408-17412$

41. O'Halloran DJ, Jones PM, Steel JH, Gon G, Giaid A, Ghatei MA, Polak JM, Bloom SR 1990 Effect of endocrine manipulation on anterior pituitary galanin in the rat. Endocrinology 127:467-475

42. Shivers BD, Harlan RE, Morrell JI, PfaffDW 1983 Absence of oestradiol concentration in cell nuclei of LHRH-immunoreactive neurones. Nature 304:345-347

43. Alexander MJ, Dobner PR, Miller MA, Bullock BP, Dorsa DM Leeman SE 1989 Estrogen induces neurotensin/neuromedin $N$ mes- 
senger ribonucleic acid in a preoptic nucleus essential for the preovulatory surge of luteinizing hormone in the rat. Endocrinology 125:2111-2117

44. Alexander MJ, Mahoney PD, Ferris CF, Carraway RE, Leeman SE 1989 Evidence that neurotensin participates in the central regulation of the preovulatory surge of luteinizing hormone in the rat. Endocrinology 124:783-788

45. Nabekura J, Oomura Y, Minami T, Mizuno Y, Fukuda A 1986 Mechanism of the rapid effect of 17-beta-estradiol on medial amygdala neurons. Science 233:226-228

46. Hua SY, Chen YZ 1989 Membrane receptor-mediated electrophysiological effects of glucocorticoid on mammalian neurons. Endocrinology 124:687-691

47. Towle AC, Sze PY 1983 Steroid binding to synaptic plasma membrane: differential binding of glucocorticoids and gonadal steroids. J Steroid Biochem 18:135-143

48. Kaplan LM, Hooi SC, Abraczinskas DR, Strauss RM, Davidson MB, Hsu DW, Koenig JI 1990 Neuroendocrine regulation of galanin gene expression. In: Hokfelt T, Bartfai T, Jacobowitz D, Ottoson D (eds) Galanin: A New Multifunctional Peptide in the Neuro-Endo- crine System. Macmillan Press, London, pp 43-65

49. Csikos T, McDonald JK, Koenig JI, Estrogen induction of galanin, immediate early gene expression in the rat anterior pituitary gland 22nd Annual Meeting of the Society for Neuroscience, Anaheim, CA, 1992, p 1086 (Abstract)

50. Zeitler PJ, Argente J, Chowen-Breed J, Clifton DK, Steiner RA 1990 Growth hormone-releasing hormone messenger ribonucleic acid in the hypothalamus of the adult male rat is increased by testosterone. Endocrinology 127:1362-1368

51. Chowen-Breed JA, Steiner RA, Clifton DK 1989 Sexual dimorphism and testosterone-dependent regulation of somatostatin gene expression in the periventricular nucleus of the rat brain. Endocrinology 125:357-362

52. Chowen-Breed J, Fraser HM, Vician L, Damassa DA, Clifton DK, Steiner RA 1989 Testosterone regulation of proopiomelanocortin messenger ribonucleic acid in the arcuate nucleus of the male rat. Endocrinology 124:1697-1702

53. Wiemann JN, Clifton DK, Steiner RA 1989 Pubertal changes in gonadotropin-releasing hormone and proopiomelanocortin gene expression in the brain of the male rat. Endocrinology 124:17601767 